\title{
The link between Internet investor relations and information asymmetry
}

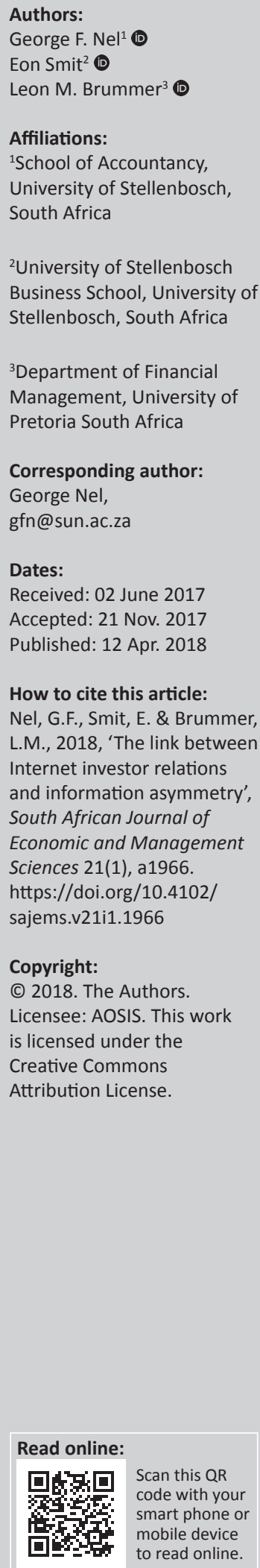

Background: Information asymmetry manifests when one party has more or better information than the other. Information asymmetry is said not only to increase transaction costs and decrease liquidity, but also to diminish the quality of the investment decisions taken by investors, thus weakening the overall functioning of markets.

Aim and setting: A well-developed Internet investor relations (IIR) strategy, coupled with increased disclosure levels, should theoretically decrease information asymmetry levels. The majority of related studies to date used either an indirect disclosure proxy or involved an examination of the annual report, and have used data from United States or European companies. Empirical studies to date have produced mixed results. The aim of this study was to ascertain whether a relationship exists between the quality of IIR (via corporate websites) and information asymmetry.

Method: This study used data from Johannesburg Stock Exchange (JSE)-listed companies. Multiple regression analysis was applied with information asymmetry as dependent variable and IIR as one of a set of selected explanatory variables. A self-constructed measurement instrument was used to measure IIR for a sample of 85 companies. Given the inherent difficulty with direct observation of information asymmetry, three different proxies were used to estimate information asymmetry.

Results: A significant negative association was found between IIR and information asymmetry for all three information asymmetry proxies that were used: bid-ask spread, price impact, and analyst following.

Conclusion: Empirical support is provided for the notion that companies may potentially benefit from a well-developed IIR strategy through reduced information asymmetry.

\section{Introduction}

In view of both the costs and the skills required to gather information, not all investors are necessarily equally informed, resulting in there being both informed and uninformed investors. Brown and Hillegeist (2007) and Chang et al. (2008:376) described information asymmetry as the situation where some investors have access to private information ('informed investors') while others only possess publicly available information ('uninformed investors'). The separation of ownership (investors) and control (management), coupled with conflicting incentives between investors and managers, may further result in management having superior information about the company, relative to the investors. Information asymmetry may therefore exist, either between the management of a company and its investors, and/or between investors themselves. Akerlof (1970) first pointed out the negative effects of information asymmetry on the effective functioning of markets. Amongst others, information asymmetry hinders the ability of investors to distinguish between good and bad investment opportunities (Healy \& Palepu 2001), creates additional costs through promoting adverse selection (Leuz \& Verrechia 2000:92; Welker 1995:802) and decreases liquidity levels (Gajewski \& Li 2015:117; Lev 1988).

Empirical studies to date that have examined the effect of disclosure on information asymmetry produced mixed results. Possible reasons for such mixed results include: different proxies used for disclosure and information asymmetry; different research methodologies (e.g. sample selected); and the characteristics of the country where the data were obtained (e.g. developing or developed countries). ${ }^{1}$

1.Ajina, Sougne and Lakhal (2015), for example, found a significant negative relationship between disclosure and bid-ask spread as information asymmetry proxy, but no significant relationship between disclosure and price impact as information asymmetry proxy.

Note: This article is partially based on the first author, George F. Nel's dissertation presented for the degree of Doctor of Philosophy (PhD) in Business Management and Administration at Stellenbosch University, with Promotor Prof. E.v.d.M. Smit and co-promotor Prof. L. Brummer, received December 2016, available here: http://scholar.sun.ac.za/handle/10019.1/100275 
The majority of related studies to date have either used an indirect disclosure proxy (i.e., a proxy that is not based on an examination of the original disclosure vehicle), for example, analyst ratings issued by the Association for Investment Management and Research (Botosan \& Plumlee 2002; Brown \& Hillegeist 2007), or based on an examination of the annual report (Ajina et al. 2015; Cheng, Courtenay \& Krishnamurti 2006; De La Bruslerie \& Gabteni 2011). Studies that entail an examination of the original disclosure vehicle (e.g. content analysis using a measurement instrument) may be regarded as direct disclosure proxy studies (Hassan \& Marston 2010). As no reliable analyst ratings suitable for use in this study exist in South Africa, and owing to the inherent shortcomings and diversity of alternative measurement instruments (as discussed in the literature review), a self-constructed measurement instrument was deemed appropriate.

The corporate website as a communication medium has specific advantages for both companies and investors. For companies, it is cost-effective and flexible in format, and for investors, it may potentially be an easy, quick, cheap, complete, reliable and up-to-date source of information. Although there exists a substantial amount of research measuring the use of corporate websites as communication channel, both in South Africa (Barac 2004; Esterhuyse \& Wingard 2016; Loxton 2003; Nel \& Baard 2006; Venter 2002) and internationally (Aerts, Cormier \& Magnan 2007; Chang et al. 2008; Froidevaux 2004; Gajewski \& Li 2015; Orens et al. 2010; Trabelsi, Labelle \& Dumontier 2008), the measurement instruments used by such studies are often criticised (as discussed in the literature review) and few of these studies explicitly measured investor relations.

The purpose of this study was to test for the association between the quality of Internet investor relations (IIR) and information asymmetry by examining the corporate websites of a sample of Johannesburg Stock Exchange (JSE)listed companies. Gray, Radebaugh and Roberts (1990) found that voluntary disclosure items (e.g. IIR) that are perceived to be useful in one country are not always valuable in other countries. Aerts et al. (2007) and Orens et al. (2010), for example, documented variations in the associations between disclosure and information asymmetry given the institutional regime.

\section{Literature review}

The purpose of the literature review is threefold: to clarify the theoretical basis for the research, to review the literature regarding the measurement of IIR and information asymmetry, and to identify independent variables, besides IIR, co-producing variations in information asymmetry.

(footnote 1 continues...)

Regarding the characteristics of the country where the data were obtained, Orens, Aerts and Cormier (2010) found a significant negative relationship between disclosure and bid-ask spread using data from Continental European listed companies, but no significant relationship using data from Northern American listed companies, but
companies.

\section{Disclosure and information asymmetry}

Brown and Hillegeist (2007) proposed two theories to explain how disclosure quality relates to information asymmetry.

According to theory 1, depicted by the upper branch in Figure 1, disclosure quality will decrease either one or both of the available sets of private information and the expected net benefits of searching for private information, which results in a decrease in private information search activities. Private information will thus lose its value once the information is published (e.g. on a corporate website), and disclosure quality will, therefore, decrease the available set of private information.

Public information will also reduce the incentives for investors, either to gather information privately or to buy the information from information intermediaries. Disclosure quality will therefore diminish the expected net benefits for investors to search for private information, which is already freely available publicly.

Theory 2, as depicted by the lower branch in Figure 1, is based on the argument that as information asymmetry depends on the balance between the informed and the uninformed (Gajewski \& Li 2015:117), disclosure quality will decrease information asymmetry through reducing the relative amount of privately-informed trading. Based on the investor recognition hypothesis (Merton 1987), uninformed investors are more likely to invest in companies with which they are familiar. The lower branch of Figure 1, however, suggests that increased levels of uninformed trading may also increase the levels of informed trading.

Although Brown and Hillegeist (2007:472) found a positive association between disclosure and uninformed trading, they concluded that this association is offset by a positive association between disclosure quality and the level of informed trading. Brown and Hillegeist (2007) therefore conclude that the association between disclosure quality and information asymmetry is primarily driven by theory 1 .

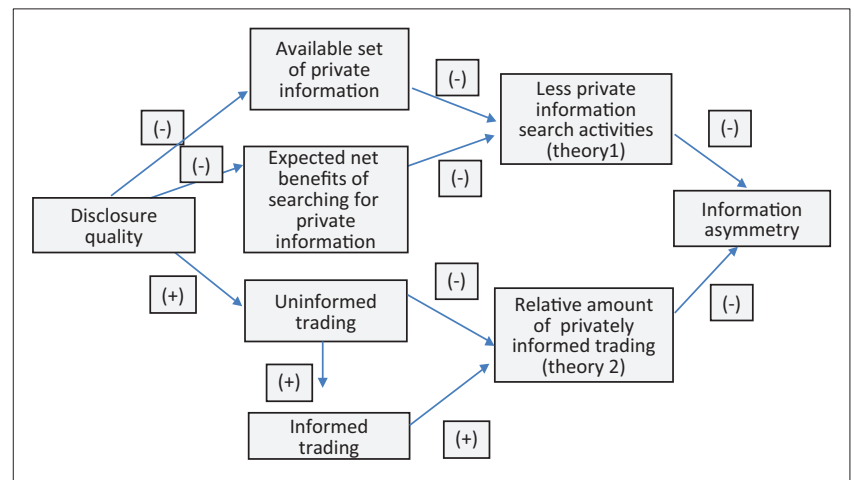

Source: Brown, S. \& Hillegeist, S.A., 2007, 'How disclosure quality affects the level of information asymmetry', Review of Accounting Studies 12(2), 448. https://doi.org/10.1007/ s11142-007-9032-5

FIGURE 1: The relationship between disclosure, private information search activities, privately informed trading and information asymmetry. 
In view of the fact that investors require information in order to evaluate investments, they will either: (1) privately gather the required information; (2) buy the required information from other information intermediaries who have already collected and analysed the information; (3) not invest in the company; or (4) make a wrong investment decision (Healy \& Palepu 2001). In view of the cost and the knowledge required to gather information, not all investors will be equally informed. Private information in the context of this study therefore refers to information that is most probably available in the public domain but, due to cost and/or time constraints, is not available to all investors - the so-called uninformed investors.

Ashbaugh, Johnstone and Warfield (1999:255), on the other hand, reason that IIR may increase or decrease information asymmetry across investors. If all investors have equal access to and expertise in the use of corporate websites as information source, IIR may decrease information asymmetry, but, if not, IIR may actually increase information asymmetry. Given the development of information technologies since 1999 , specifically the increased levels of accessibility to the worldwide web (Internet), it follows that investors have since consolidated achieving equal access and greater expertise in the use of corporate websites as information source. Ashbaugh et al. (1999) further argued that IIR would increase information asymmetry if IIR activities were dominated by unreliable information communicated to uninformed investors, stressing the importance of reliable and useful IIR.

\section{Measurement of Internet investor relations}

Marston (1996:477) defined investor relations as the link between a company and the financial community by means of which information is provided (i.e., disclosed) to the financial community as basis for the evaluation of the company. The activities of investor relations embody a range of information or disclosure types, for example mandatory and voluntary, financial and non-financial, as well as shareholder services to facilitate relationship management and/or strategic marketing.

Measurement instruments devised in the literature to measure the use of corporate websites as communication channel, frequently fall short in key aspects (Nel \& Brummer 2016) by:

- ignoring important attributes (e.g. by merely measuring the level of financial reporting on corporate websites without attempting to measure the wider concept of investor relations and presentation-related attributes);

- not attempting to distinguish between quantity and quality or to measure quality;

- using weights without a clear rationale; and

- failing to perform the required reliability and validity tests.

The measurement instrument used in this study is further discussed in the methodology section.

\section{Measurement of information asymmetry}

Leuz and Verrecchia (2000:98) argued that as it is not possible to observe information asymmetry directly, an appropriate proxy should be used. A number of studies have used different proxies for information asymmetry (e.g. Ajina et al. 2015; Fu, Kraft \& Zhang 2012; Gajewski \& Li 2015; Orens et al. 2010). Three are retained here - the quoted or relative bid-ask spread, price impact, and analyst following. For reasons discussed below, the following proxies were not used: analyst forecast accuracy, time-weighted average spread, effective spread, depth-adjusted effective spread, and the probability of informed trading. ${ }^{2}$

Analyst forecast accuracy is based on analyst forecast dispersion. At least two analyst forecasts are required to calculate this measure and, as only 30 of the companies in the study sample are followed by two or more analysts, it was decided not to use this proxy. To calculate the time-weighted, effective, and depth-adjusted effective spread, as well as the probability of informed trading, intraday data are needed. Given, firstly, the difficulties of accessing intraday data and, secondly, the similarity of results derived from alternative proxies, ${ }^{3}$ intraday-based proxies were not utilised.

\section{Bid-ask spread}

The bid-ask spread, also known as the width or tightness, is calculated as the difference between the bid and the ask price. Of all the variations of the bid-ask spread used in the literature (e.g. quoted or relative, time-weighted relative, effective and depth-adjusted effective spreads), the quoted bid-ask spread is the most popular.

Chang et al. (2008:382) asserted that periods of high information asymmetry are characterised by uninformed traders that revise their bid and ask prices away from the market to decrease the probability of trading with an informed investor. The bid-ask spread therefore has a positive correlation with information asymmetry and if IIR decreases this adverse selection, it should result in a narrowing of the bid-ask spread.

\section{Price impact}

Liquidity can be described using three dimensions: width (bid-ask spread), market depth, and slippage (Kyle 1985).

2 Although share turnover (e. Cheng et al. 2006: Orens et al. 2010) and share price volatity (e. Cheng et al. 2006. Luz \& Verrechia 2000) are sometimes used as information asymmetry proxies and were tested as such in this study, the results information asymmetry proxies and were tested as such in this study, the results
thereof are not reported due to inherent limitations in the research design (e.g. endogeneity). For completeness' sake, IIR was found to be a significant positive independent variable (at $5 \%$ ) and, together with share price, share price volatility and free float (all significant and positive), explained $51 \%\left(R^{2}\right)$ of the variation in share turnover. Share turnover was measured as the average daily of the rand volume of shares traded scaled by the market capitalisation (over-all trading days from 01 December 2014 to 30 November 2015). With regard to share price volatility, no significant association was found between IIR and share price volatility where the latter was measured as the natural logarithm of the annualised share price volatility as on 30 November 2015

3.Gajewski and Li (2015) studied the relationship between internet-based disclosure and information asymmetry. They used five proxies for information asymmetry (i.e. quoted spread, effective spread, time-weighted spread, probability of informed trading [PIN] and adjusted PIN) and found negative associations with disclosure for all five proxies. Ajina et al. (2015) found statistically-significant negative relationships all five proxies. Ajina et al. (2015) found statistically-significant negative relationships
between both the quoted and the effective bid-ask spread, and their disclosure proxy (voluntary disclosure in annual reports). 
Slippage (also referred to as market resilience) captures the ability of investors to trade in a share without affecting its price. The price impact ratio was developed by Amihud (2002) to capture slippage and is positively correlated with information asymmetry. If IIR increases liquidity and decreases information asymmetry, it should be negatively related to the price impact ratio as small changes in the share price will result in a lower price impact ratio.

\section{Analyst following}

Lang and Lundholm (1996) argued that both the effectiveness of analysts monitoring, as well as market efficiency in a particular company's shares, are improved if the number of analysts following the company increases.

Merton (1987) and Agarwal et al. (2016:35) argued that an effective investor relations programme increases analyst following. Healy and Palepu (2001), on the other hand, argued that one can either reason that companies which disclose more information attract more analysts by supporting these analysts to create superior forecasts, or that additional disclosure reduces the opportunities for analysts, implying a lower demand for their services leading to a lower analyst following.

Based on the argument that reliable analyst monitoring and ratings may potentially both increase uninformed trading (theory 2 in Figure 1) and decrease private information search activities (theory 1 in Figure 1), as discussed earlier, for present purposes a negative association between analyst following and information asymmetry was hypothesised.

\section{Determinants of information asymmetry}

Independent variables, beyond IIR, used in the literature to explain variations in information asymmetry, are discussed in this section.

\section{Share price}

The microstructure of financial markets stipulates that the share price should explain liquidity (Ajina et al. 2015:1228). Significant negative associations have been documented between share price and the following information asymmetry proxies: quoted bid-ask spread (Ajina et al. 2015; Healy, Hutton \& Palepu 1999; Welker 1995), time-weighted spread (Chang et al. 2008) and effective spread (Ajina et al. 2015; Heflin, Shaw \& Wild 2005).

Our study expected a negative association between share price and each of the following: bid-ask spread and price impact, while a positive association was expected between share price and analyst following.

\section{Leverage}

Theoretical arguments are used in the literature to hypothesise both positive (Aerts et al. 2007; Boot \& Thakor 1993) and negative associations (Brown \& Hillegeist 2007) between leverage and information asymmetry.
Boot and Thakor (1993) argued that higher levels of leverage will stimulate private information production, which will increase information asymmetry. In support of arguments for a positive association, Orens et al. (2010) found a significant positive association between leverage and the bid-ask spread.

Our study expected a positive association between leverage and each of the following: bid-ask spread and price impact. A negative association was expected between leverage and analyst following.

\section{Share price volatility}

According to Orens et al. (2010:1072), share price volatility results from disagreements between buyers and sellers, and can therefore be associated with the requirement of higher risk premiums, which, in turn, will increase the bid-ask spread. Share price volatility indicates the degree of uncertainty or risk (Gajewski \& Li 2015) used as a measure of the price risk that investors have to bear (Welker 1995:808).

Bhushan (1989:271) found a positive association between share price volatility and analyst coverage, suggesting that the demand for analysts' services is higher for companies with a higher risk, as measured by share price volatility. Our study expected a positive association between share price volatility and each of the following: bid-ask spread, price impact, and analyst following.

\section{Ownership structure}

Information asymmetry is related to the extent to which privately-informed trading takes place and to private information search activities. Large institutional investors not only have the resources to generate private information, but also benefit from economies of scale - which will further decrease their information acquisition cost relative to smaller retail investors.

The present study has used two ownership structure proxies, directors' shareholding and free float. Our study expected a positive association between directors' shareholding and each of the following: bid-ask spread and price impact; while a negative association was expected between directors' shareholding and analyst following. For free float, on the other hand, negative associations were expected with the bid-ask spread and price impact, and a positive association with analyst following.

\section{Share turnover}

Trading volume consists of both informed and uninformed trading. As discussed, it can be hypothesised that informed trading increases information asymmetry and uninformed trading decreases information asymmetry. Ajina et al. (2015) argued that increased levels of trading volume may cause disequilibrium in the market, resulting in extra costs that have to be recouped by the enlargement of the spread. 
Although the relationship between share turnover and information asymmetry is therefore somewhat ambiguous, the majority of studies to date found a negative association between share turnover, as independent variable, and information asymmetry, as dependent variable. Our study expected a negative association between share turnover, as independent variable, and each of the following: bid-ask spread and price impact. Analysts would be attracted to more visible companies. A positive association between share turnover, as independent variable, and analyst following was therefore expected.

\section{Dual listing}

Multiple stock exchange listings are often associated with increased transparency and increased disclosure (Ajina et al. 2015:1229; Orens et al. 2010:1070). Our study expected a negative association between having a dual listing and each of the following: bid-ask spread and price impact. A foreign listing may, however, stimulate analyst activity in the foreign country, as foreign investors will experience more information asymmetry compared to domestic investors, thereby creating a demand for analyst research in the foreign country (Aerts et al. 2007:1311). Our study expected a positive association between having a dual listing and analyst following.

\section{Methodology \\ Measurement of Internet investor relations}

The measurement instrument was developed by means of a four-step methodology: review of best practices as published by the United Kingdom Investor Relations Society (http://irsociety.org.uk/); an extensive literature review of existing instruments; a pilot study; and, finally, a reliability (Cronbach's alpha) and construct validity assessment based on the IIR measurement results, resulting in a measurement instrument that consists of 346 attributes, organised into 11 categories. ${ }^{4}$ The maximum IIR score that could be achieved was 346. More specifically, quality of IIR is assessed by, first of all, measuring information content in as detailed a manner as possible; second, by measuring the presentation of information (i.e. accessibility, timeliness and navigation); and, finally, by allowing for the measurement of attributes as only partially available (scored as 0.5 ) based on breadth, timeliness and usability.

A sample of $25 \%$ of JSE-listed companies was selected using stratified (JSE industry) random sampling with proportional allocation per JSE sector. The population was defined as all companies $^{5}$ currently listed on the JSE that had not been

\footnotetext{
4.The 11 categories are: accessibility, navigation, timeliness, company information, financial information, relevant news, investment case, shareholder information, bondholder information, corporate governance and corporate responsibility. Space precludes the publication of the full measurement instrument, but all issues in the development of the instrument (e.g. reliability and validity tests performed) are comprehensively dealt with in Nel and Brummer (2016). The full measurement instrument, as well as the measurement conventions followed in the measurement process, is further available from the author on request.

5.Both companies listed on the Main Board and AltX were included in the population. Although it is acknowledged that AltX companies might have different trading behaviour (e.g. liquidity) and ownership structures compared to companies listed behaviour (e.g. liquidity) and ownership structures compared to companies listed
on the main board, they were specifically included for the following reasons: smaller companies are more likely to use their disclosure policy to influence market
}

suspended, had traded since the inception date, had published 2013 annual reports, and had a dedicated, working website. A total of 85 companies were included in the sample. All IIR measurements were done from March to September 2015.

\section{Information asymmetry}

Table 1 provides a brief description of how each information asymmetry proxy was calculated, as well as the expected association with IIR.

In theory, the first two proxies listed in Table 1, bid-ask spread and price impact, are positively related to information asymmetry and the last one, analyst following, negatively.

\section{Additional independent variables}

The stepwise regression method was used to examine the relationship between IIR and each of the three proxies used for information asymmetry. Besides IIR, additional independent variables were used in the regression analysis to explain further variation in information asymmetry. Table 2 summarises the calculation of these variables.

\section{Data collection}

All dependent and independent variables were captured from the INET BFA database with the exception of dual listing and free float that were obtained directly from the JSE, and IIR which was measured using the measurement instrument discussed above.

\section{Endogeneity}

Various studies to date have cautioned that disclosure, and therefore IIR, should be treated as an endogenous variable when studying the effects of voluntary disclosure on information asymmetry (Chang et al. 2008; Core 2001; Leuz \& Verrechia 2000; Orens et al. 2010; Welker 1995). If not accounted for, the endogeneity problem will result in

TABLE 1: Information asymmetry proxies - Description and expected IIR association.

\begin{tabular}{lll}
$\begin{array}{l}\text { Information } \\
\text { asymmetry proxy }\end{array}$ & Description & $\begin{array}{l}\text { Predicted } \\
\text { direction }\end{array}$ \\
\hline Bid-ask spread & $\begin{array}{l}\text { Natural logarithm of the median of the daily } \\
\text { difference between the last offer or ask (selling } \\
\text { price) and last bid (buying price) scaled by the } \\
\text { daily average of the last offer and last bid price } \\
\text { (over all trading days from 01 December 2014 } \\
\text { to 30 November 2015) }\end{array}$ & - \\
Price impact & $\begin{array}{l}\text { Natural logarithm of the median of the daily } \\
\text { absolute return scaled by the daily rand value } \\
\text { of shares traded (over all trading days from 01 } \\
\text { December 2014 to 30 November 2015) }\end{array}$ & - \\
\hline Analyst following & $\begin{array}{l}\text { The number of analysts following the company, } \\
\text { that is, the number of analysts that issue e.g. } \\
\text { earnings per share forecasts per company as } \\
\text { available on the INET BFA database }\end{array}$ & + \\
\hline
\end{tabular}

(footnote 5 continues...)

perceptions (Lang \& Lundholm 2000) and research that found significant associations between disclosure/investor relations and, respectively, the cost of equity (Botosan 1997) and analyst following (Agarwal et al. 2016) for smaller equity (Botosan 1997) and analyst following (Agarwal et al. 2016) for smaller
companies/companies with a low analyst following, but none for larger companies/ companies with a high analyst following. 
spurious results and incorrect conclusions. Hence, the $\mathrm{Wu}-$ Hausman test was used to test for endogeneity.

\section{Results}

As a result of extremely thin trading, the bid-ask spread was not available for one company, as this company's shares only traded for 40 days over the measurement period. The sample was therefore reduced to 84 companies. All the results reported pertain to the reduced sample. The natural logarithm (ln) of the bid-ask spread, price impact, share price volatility and share price were used to reduce skewness. However, the descriptive statistics in Table 3 are presented prior to the use of any natural logarithmic transformations in the multivariate regression analysis.

Table 4 shows the Pearson correlation coefficients between the three information asymmetry proxies and the independent variables.

All the coefficients reported in Table 4 are as expected, except in three instances. First, no significant association between dual listing and any of the three information asymmetry proxies was found. Dual listing was, however, found to be significant, and negative as expected, in the regression model where the bid-ask spread was used as information asymmetry proxy.

TABLE 2: Independent variables used to explain information asymmetry: Description.

\begin{tabular}{|c|c|}
\hline Variable & Description \\
\hline Share price & $\begin{array}{l}\text { Natural logarithm of the average daily closing share } \\
\text { price (over all trading days from } 01 \text { December } 2014 \text { to } \\
30 \text { November 2015) }\end{array}$ \\
\hline Leverage & Ratio between debt and assets \\
\hline Share price volatility & $\begin{array}{l}\text { Natural logarithm of the annualised share price } \\
\text { volatility as on } 30 \text { November } 2015\end{array}$ \\
\hline Free float percentage & $\begin{array}{l}\text { Ratio between the total issued shares minus restricted } \\
\text { shares to the total issued shares }\end{array}$ \\
\hline $\begin{array}{l}\text { Directors' shareholding } \\
\text { percentage }\end{array}$ & $\begin{array}{l}\text { The percentage of direct and indirect, beneficial and } \\
\text { non-beneficial shareholding of directors }\end{array}$ \\
\hline Share turnover & $\begin{array}{l}\text { Average daily of the rand volume of shares traded } \\
\text { scaled by the daily market capitalisation (over all } \\
\text { trading days from } 01 \text { December } 2014 \text { to } 30 \text { November } \\
\text { 2015) }\end{array}$ \\
\hline Dual listing & $\begin{array}{l}\text { Dummy variable representing one if the company is } \\
\text { dually listed on the JSE or any other stock exchange, } \\
\text { and zero if otherwise }\end{array}$ \\
\hline
\end{tabular}

Second, the association between leverage and information asymmetry was expected to be positive in the case of the first two proxies (bid-ask spread and price impact) and negative in the case of the last one, analyst following. Table 4, however, depicts associations contrary to what were expected.

Lastly, a positive association was expected between share price volatility, as independent variable, and analyst following, as information asymmetry proxy. Although Table 4 depicts a negative association, a significant and positive association was found in the respective regression model, as discussed below (see Table 7).

Table 5 displays the Pearson correlation coefficients between the independent variables.

The high correlations between share price and share price volatility, and free float and share turnover send cautionary signals that tolerance values should be carefully monitored for signs of multicollinearity.

As discussed above, the Wu-Hausman test is used to test for a potential endogenous problem. An instrumental variable is needed to perform the Wu-Hausman test. For the purpose of this study, being audited by a big four audit company was used as the instrumental variable. Being audited by a big four audit company is highly significant and positively related to the endogenous independent variable, IIR, (Nel, Smit \& Brummer 2017:63), but is not correlated with information asymmetry. The $\mathrm{Wu}-\mathrm{Hausman}$ test results are showed in Table 6.

The Wu-Hausman test also tests for the strength of the instrumental variable used. For each of the three information asymmetry proxies tested in this study, the Ho hypothesis that the instrumental variable is a weak instrument was tested. As the $p$-values in Table 6 indicate, all three hypotheses were rejected, thus showing the strength of the instrumental variable used.

Next, the Ho hypothesis that IIR is an exogenous variable was tested. As the $p$-values in Table 6 indicate, none of these hypotheses were rejected. All three Ho hypotheses were

TABLE 3: Descriptive statistics.

\begin{tabular}{|c|c|c|c|c|c|c|c|c|}
\hline \multirow[t]{2}{*}{ Panel } & \multirow[t]{2}{*}{ Variable } & \multirow[t]{2}{*}{ Average } & \multirow[t]{2}{*}{ Minimum } & \multicolumn{3}{|c|}{ Quartile } & \multirow[t]{2}{*}{ Maximum } & \multirow{2}{*}{$\begin{array}{l}\text { Standard } \\
\text { deviation }\end{array}$} \\
\hline & & & & Q1 & Q2 & Q3 & & \\
\hline \multirow{3}{*}{$\begin{array}{l}\text { A: Dependent } \\
\text { variables }\end{array}$} & Bid-ask spread & 0.0472 & 0.0011 & 0.0028 & 0.0065 & 0.0394 & 0.4783 & 0.0876 \\
\hline & Price impact & 254.60 & 2.96 & 7.36 & 21.11 & 125.49 & 3540.92 & 626.75 \\
\hline & Analyst following & 2.31 & 0 & 0 & 1 & 3 & 11 & 3.33 \\
\hline \multirow{7}{*}{$\begin{array}{l}\text { B: Continuous } \\
\text { independent } \\
\text { variables }\end{array}$} & Internet investor relations (IIR) & 98.70 & 13.50 & 69.25 & 96.25 & 130.63 & 193.50 & 42.73 \\
\hline & Share price & R65.79 & R0.03 & R4.04 & R18.89 & R111.46 & R696.21 & R102.40 \\
\hline & Leverage & 0.45 & 0.00 & 0.28 & 0.40 & 0.61 & 1.21 & 0.24 \\
\hline & Share price volatility & 51.40 & 17.68 & 26.23 & 35.16 & 57.24 & 455.89 & 54.74 \\
\hline & Free float $\%$ & 59.43 & 2.50 & 36.00 & 60.00 & 87.50 & 100 & 28.70 \\
\hline & Directors' shareholding \% & 13.93 & 0.00 & 0.09 & 2.80 & 23.23 & 81.79 & 20.58 \\
\hline & Share turnover & 0.0015 & 0.00003 & 0.0004 & 0.0012 & 0.0022 & 0.0049 & 0.0012 \\
\hline \multirow{2}{*}{$\begin{array}{l}\text { C: Categorical } \\
\text { independent } \\
\text { variables }\end{array}$} & - & 1 & 0 & Total & - & - & - & - \\
\hline & Dual listing & 25 & 59 & 84 & & & & \\
\hline
\end{tabular}


therefore accepted, thus showing that IIR is not an endogenous independent variable. Similar results were found by Cheng et al. (2006) and Gajewski and Li (2015). The ordinary least square regression model is therefore used in all further analyses discussed in the remainder of this article.

Table 7 presents the results of the stepwise regressions.

A minimum tolerance value of 0.31 confirmed the absence of multicollinearity. Residual plots of predicted versus residuals were examined. From these residual plots no evidence of heteroscedasticity was found for the bid-ask spread and price impact model. The residual plot for analyst following, however, depicts evidence of heteroscedasticity. The BreuschPagan test for heteroscedasticity confirmed the existence of heteroscedasticity. The regression results reported in Table 7 are before adjustments were made for heteroscedasticity. Regression results, adapted for heteroscedasticity, are discussed below.

\section{Bid-ask spread}

As depicted in Table 7, the coefficient for IIR is negative and significant at the $1 \%$ level. The coefficients of all other independent variables are as expected and highly significant, except for dual listing that is only significant at the $10 \%$ level.

For the sample of JSE companies the following hold in accordance with theoretical expectation: the negative IIR coefficient indicates that enhanced IIR reduces the level of the bid-ask spread, and therefore information asymmetry. Most studies to date that have found a similar negative association, have used either an indirect disclosure proxy (e.g. analyst ratings) or measured the annual report as

TABLE 4: Correlation matrix: Information asymmetry and independent variables.

\begin{tabular}{lccc}
\hline Independent variables & \multicolumn{3}{c}{ Dependent variables } \\
\cline { 2 - 4 } & Bid-ask spread & Price impact & Analyst following \\
\hline Internet investor relations & $-0.64 * * *$ & $-0.57 * * *$ & $0.57 * * *$ \\
Share price & $-0.88 * * *$ & $-0.79 * * *$ & $0.55^{* * *}$ \\
Leverage & $-0.26 * *$ & $-0.26 * *$ & $0.24 * *$ \\
Share price volatility & $0.79 * * *$ & $0.74 * * *$ & $-0.25 * *$ \\
Free float & $-0.50 * * *$ & $-0.57 * * *$ & $0.34 * * *$ \\
Directors' shareholding & $0.35 * * *$ & $0.35 * * *$ & $-0.26 * *$ \\
percentage & & & \\
Share turnover & $-0.63 * * *$ & $-0.76 * * *$ & $0.66 * * *$ \\
Dual listing & -0.09 & 0.05 & 0.14 \\
\hline$* * *$ Significant at the $1 \%$ level $* *$ significant at the $5 \%$ level: $[*$ significant at the $10 \%$ level]
\end{tabular}

disclosure vehicle. However, Gajewski and Li (2015) and Orens et al. (2010) have found a negative association based on a measurement of corporate website disclosure.

On the other hand, Chang et al. (2008) found no significant association between spread and their measurement of the quality of a company's IIR activities. Chang et al. (2008:386) suggested two possible reasons for this non-significant association:

- Website investor relations information may be perceived to be less credible by investors compared to annual report-provided disclosures; and

- The possibility of a non-linear relationship between disclosure and spread, suggesting that that there may be an upper limit in the reduction of spread as disclosure quality improves.

The magnitude of the reported adjusted $R^{2}$ of $91 \%$ compares favourably with studies such as Gajewski and Li (2015) reporting an adjusted $R^{2}$ of $60 \%$, Welker (1995) 63\%, Ajina et al. (2015) 74\%, Leuz and Verrechia (2000) $81 \%$, and Cheng et al. (2006) $85 \%$.

Although various studies have used share turnover as independent variable in their regression models to explain variations in bid-ask spread levels (e.g. Ajina et al. 2015; Gajewski \& Li 2015), a reverse causality relationship may exist between share turnover and the bid-ask spread. If share turnover as independent variable is removed from the regression model reported in Table 7, dual listing does not remain as a significant independent variable in the final regression result. Share price, IIR and share price volatility are, however, still highly significant at $1 \%$, and free float remains as significant independent variable (direction of all coefficients as expected) with only a slight decrease in the adjusted $R^{2}$ to $88 \%$ from the $91 \%$ reported in Table 7 .

\section{Price impact}

As depicted in Table 7, the coefficient for IIR, for the JSE sample, is negative and significant, but only at the $10 \%$ level. The coefficients of all other independent variables are as expected and highly significant. The negative IIR coefficient indicates that enhanced IIR improves the ability of investors to trade in a share without affecting its price, resulting in increased liquidity levels and decreased information asymmetry.

TABLE 5: Correlation matrix: Independent variables.

\begin{tabular}{|c|c|c|c|c|c|c|c|c|}
\hline Variable & IIR & SP & LEV & SPV & F.FLT & DIR.SH & STO & LIST.D \\
\hline Internet investor relations & 1.00 & - & - & - & - & - & - & - \\
\hline Share price & $0.52^{* * *}$ & 1.00 & - & - & - & - & - & - \\
\hline Leverage & $0.36 * * *$ & $0.29 * * *$ & 1.00 & - & - & - & - & - \\
\hline Share price volatility & $-0.33 * * *$ & $-0.76 * * *$ & $-0.25 * *$ & 1.00 & - & - & - & - \\
\hline Free float & $0.39 * * *$ & $0.39 * * *$ & 0.03 & $-0.31 * * *$ & 1.00 & - & - & - \\
\hline Directors' shareholding & $-0.31 * * *$ & $-0.26 * *$ & -0.01 & $0.20 *$ & $-0.39 * * *$ & 1.00 & - & - \\
\hline Dual listing & $0.26 * *$ & 0.04 & -0.11 & 0.09 & -0.05 & $-0.31 * * *$ & -0.01 & 1.00 \\
\hline
\end{tabular}

***Significant at the $1 \%$ level; **significant at the $5 \%$ level; *significant at the $10 \%$ level.

IIR, Internet investor relations; SP, share price; LEV, leverage; SPV, share price volatility; F.FLT, free float; DIR.SH, directors' shareholding; STO, share turnover; List.D, dual listing. 
TABLE 6: Wu-Hausman results: Internet investor relations as independent variable and information asymmetry as dependent variable.

\begin{tabular}{lcc}
\hline Dependent variable & Weak instrument $\boldsymbol{p}$-value & IIR exogenous $\boldsymbol{p}$-value \\
\hline Bid-ask spread & 0.02 & 0.79 \\
Price impact & 0.01 & 0.28 \\
Analyst following & 0.01 & 0.31 \\
\hline
\end{tabular}

TABLE 7: Regression results

\begin{tabular}{lccc}
\hline Variable & Bid-ask spread & Price impact & Analyst following \\
\hline Constant ( $\beta 0)$ & $-5.36 * * *$ & 0.68 & $-11.21 * * *$ \\
IIR & $-0.01 * * *$ & $-0.004 *$ & $0.02 * *$ \\
Share price & $-0.61 * * *$ & $-0.28 * *$ & $1.468 * * *$ \\
Share turnover & $-368.84 * * *$ & $-840.77 * * *$ & $1133.06 * * *$ \\
Share price volatility & $1.109 * * *$ & $1.449 * * *$ & $1.50 * *$ \\
Dual listing & $-0.26 *$ & - & - \\
Adjusted $R^{2}(\%)$ & $91.18 \%$ & $89.55 \%$ & $54.14 \%$ \\
F-value & 172.57 & 178.84 & 25.49 \\
\hline
\end{tabular}

***, Significant at the $1 \%$ level; $* *$, significant at the $5 \%$ level; $*$, significant at the $10 \%$ level. $\mathrm{IIR}$, internet investor relations.

Compared to the bid-ask spread as information asymmetry proxy, few studies have used the price impact ratio as measure of information asymmetry giving rise to mixed empirical results. Fu et al. (2012), for example, found the expected negative association, whereas Ajina et al. (2015) found no significant association. Neither of these two studies however measured corporate website disclosure levels or investor relations levels. Fu et al. (2012) used an indirect disclosure proxy, namely financial reporting frequency, and Ajina et al. (2015) measured annual report voluntary disclosure levels. Fu et al. (2012) reported an adjusted $R^{2}$ of $36 \%$ and Ajina et al. (2015) a higher $67 \%$, but with a nonsignificant disclosure coefficient.

\section{Analyst following}

Table 7 shows the expected positive association between IIR, significant at the 5\% level, and analyst following for the JSE sample. The coefficients of all other independent variables are as expected and significant.

The Breusch-Pagan test confirmed the existence of heteroscedasticity. Corrected for heteroscedasticity, by applying heteroscedasticity-consistent estimation of the covariance matrix of the coefficient estimates, the IIR coefficient remained positive with the level of statistical significance unchanged at 5\%. In the adapted regression model, the statistical significance of the share price volatility variable, however, increased to the $1 \%$ level.

Orens et al. (2010:1078) discussed a problem of endogeneity with the extent of disclosure. They argued that either financial analysts are more likely to follow companies with more disclosure or companies may disclose more in order to attract more analysts. As discussed, the Wu-Hausman test results confirmed the absence of endogeneity. Similar results (i.e., significant association between analyst following and IIR, as well as the absence of endogeneity) were reported by Abdelsalam, Bryant and Street (2007:20).
As a high analyst following could lead to a high share turnover, a reverse causality relationship may exist between share turnover and analyst following. If share turnover as independent variable is removed from the regression model reported in Table 7, all independent variables (IIR, share price and share price volatility) remain significant. Although the adjusted $R^{2}$ decrease to $43 \%$ from the $54 \%$ reported in Table 7, the statistical significance of both IIR and share price volatility increases from $5 \%$ to $1 \%$ (direction of all coefficients as expected).

\section{Conclusion}

Of the three proxies used for information asymmetry in this study, the bid-ask spread is not only the most popular and theoretically appealing proxy, but it also provides the strongest empirical support for a negative association between IIR and information asymmetry. The majority of studies about disclosure and information asymmetry have, however, been performed using developed country data and have either used analyst ratings as disclosure proxy or have measured the annual report as disclosure vehicle. This study therefore not only provides further empirical support for a negative relationship between disclosure and information asymmetry, but more specifically provides support for the investor recognition hypothesis that states that a welldeveloped investor relations programme improves visibility and decreases information asymmetry. Specifically in respect of IIR, this study provides further support for the findings of Gajewski and Li (2015) who used a French sample, but contradicts the findings by Chang et al. (2008) who found no association using an Australian sample.

Although used far less as information asymmetry proxy, price impact seems to capture an important measure of liquidity, which is the ability of an investor to trade without affecting the share price. Empirical support for a negative association between disclosure and price impact is, however, weak and unstable. This study not only provides strong empirical support for a negative association between IIR and price impact, but also provides further support for the continuous use of price impact as illiquidity and information asymmetry proxy. Although analyst following is considered a less precise measure of information asymmetry, the positive association between IIR and analyst following support the arguments by Merton (1987) and Agarwal et al. (2016) that an effective investor relations programme will increase analyst following.

This study therefore provides further evidence in support of economic theory that postulates a relationship between disclosure and information asymmetry, by using developing country data and through the examination of corporate websites as communication medium.

Based on research that found that annual report disclosure levels are positively correlated with disclosure levels through corporate investor relations and other publications 
(Lang \& Lundholm 1993) and the voluntary nature of IIR, this study contributes to international accounting literature by providing further support for the advantages of voluntary disclosure in an accounting context. Given the advantages of a reduced level of information asymmetry, knowledge about the circumstances under which and how these may be achieved would enable companies to optimise their IIR strategies.

Whereas several investor relations communication channels are available to companies, for example, media releases, investor presentations, social media (e.g. Twitter) and corporate websites, the current study examines only one of these channels, namely the corporate website.

Given the recent growth in social media channels such as Twitter, Facebook and YouTube, further research is needed on how companies use social media to communicate with investors, and to examine the effect thereof on information asymmetry. Blankespoor, Miller and White (2014), for example, found that the communication of company-initiated news via Twitter is associated with lower bid-ask spreads and higher liquidity.

Economic theory links information asymmetry to the share price and the cost of capital. This warrants the need for future research to examine the association between IIR, and the share price and cost of capital.

\section{Acknowledgements Competing interests}

The authors declare that they have no financial or personal relationships that may have inappropriately influenced them in writing this article.

\section{Authors' contributions}

G.F.N. was the primary author and analyst; E.vdM.S. acted as co-author and responsible for the research methodology and L.M.B., also co-authored the article relating to financial markets.

\section{References}

Abdelsalam, O.H., Bryant, S.M. \& Street, D.L., 2007, 'An examination of the comprehensiveness of corporate internet reporting provided by London-listed companies', Journal of International Accounting Research 6(2), 1-33. https://doi. org/10.2308/jiar.2007.6.2.1

Aerts, W., Cormier, D. \& Magnan, M., 2007, 'The association between web-based corporate performance disclosure and financial analyst behaviour under different governance regimes', Corporate Governance: An International Review 15(6), governance regimes', Corporate Governance: An International
1301-1329. https://doi.org/10.1111/j.1467-8683.2007.00648.x

Agarwal, V., Taffler, R.J., Bellotti, X. \& Nash, E.A., 2016, 'Investor relations, information asymmetry and market value', Accounting and Business Research 46(1), 31-50. asymmetry and market value', Accounting and Busin
https://doi.org/10.1080/00014788.2015.1025254

Ajina, A., Sougne, D. \& Lakhal, F., 2015, 'Corporate disclosures, information asymmetry and stock-market liquidity in France', The Journal of Applied Business Research 31(4), 1223-1237. https://doi.org/10.19030/jabr.v31i4.9297

Akerlof, G.A., 1970, 'The market for "lemons": Quality uncertainty and the market mechanism', The Quarterly Journal of Economics 84(3), 488-500. https://doi. org/10.2307/1879431

Amihud, Y., 2002, 'Illiquidity and stock returns: Cross-section and time-series effects', Journal of Financial Markets 5(1), 31-56. https://doi.org/10.1016/S1386 4181(01)00024-6
Ashbaugh, H., Johnstone, K.M. \& Warfield, T.D., 1999, 'Corporate reporting on the internet', Accounting Horizons 13(3), 241-257. https://doi.org/10.2308/ acch.1999.13.3.241

Barac, K., 2004, 'Financial reporting on the internet in South Africa', Meditari Accountancy Research 12(1), 1-20. https://doi.org/10.1108/10222529200400001

Bhushan, R., 1989, 'Firm characteristics and analyst following', Journal of Accounting and Economics 11(3), 255-274. https://doi.org/10.1016/0165-4101(89)90008-6

Blankespoor, E., Miller, G.S. \& White, H.D., 2014, 'The role of dissemination in market liquidity: Evidence from firms' use of Twitter', The Accounting Review 89(1), 79-112. https://doi.org/10.2308/accr-50576

Boot, A.W.A. \& Thakor, A.V., 1993, 'Security design', The Journal of Finance 48(4), 1349-1378. https://doi.org/10.1111/j.1540-6261.1993.tb04757.x

Botosan, C.A., 1997, 'Disclosure level and the cost of equity capital', The Accounting Review 72(3), 323-347. https://doi.org/10.1111/1475-679X.00037

Botosan, C.A. \& Plumlee, M.A., 2002, 'A re-examination of disclosure level and the expected cost of equity capital', Journal of Accounting Research 40(1), 21-40.

Brown, S. \& Hillegeist, S.A.,, 2007, 'How disclosure quality affects the level of information asymmetry', Review of Accounting Studies 12(2), 443-477. https:// doi.org/10.1007/s11142-007-9032-5

Chang, M., D’Anna, G., Watson, I. \& Wee, M., 2008, 'Does disclosure quality via investor relations affect information asymmetry?', Australian Journal of Management 33(2), 375-390. https://doi.org/10.1177/031289620803300208

Cheng, E.C.M., Courtenay, S.M. \& Krishnamurti, C., 2006, 'The impact of increased voluntary disclosure on market information asymmetry, informed and uninformed voluntary disclosure on market information asymmetry, informed and uninformed trading, Journal of Contemporary Accountin
doi.org/10.1016/S1815-5669(10)70016-3

Core, J.E., 2001, 'A review of the empirical disclosure literature: Discussion', Journal of Accounting and Economics 31(3), 441-456. https://doi.org/10.1016/S01654101(01)00036-2

De La Bruslerie, H. \& Gabteni, H., 2011, 'Voluntary financial disclosure, the introduction of IFRS and long-term communication policy: An empirical test on French firms', Paper presented at the French Finance Association Meeting, 27 October 2011, St Malo, France.

Esterhuyse, L. \& Wingard, C., 2016, 'An exploration of the online investor relations (IR) practices of companies listed on the Johannesburg Stock Exchange (JSE)', South African Journal of Economic and Management Sciences 19(2), 215-231. https://doi.org/10.4102/sajems.v19i2.1261

Froidevaux, E.A., 2004, 'Investor relations internet disclosure and the cost of equity capital', unpublished PhD dissertation, University of Fribourg, Switzerland, viewed 24 October 2012, from http://ethesis.unifr.ch/theses/downloads.php?file= FroidevauxE.pdf

Fu, R., Kraft, A. \& Zhang, H., 2012, 'Financial reporting frequency, information asymmetry, and the cost of equity', Journal of Accounting and Economics 54(2), 132-149. https://doi.org/10.1016/j.jacceco.2012.07.003

Gajewski, J. \& Li, L., 2015, 'Can internet-based disclosure reduce information asymmetry?', Advances in Accounting, incorporating Advances in International Accounting 31(1), 115-124. https://doi.org/10.1016/j.adiac.2015.03.013

Gray, S.J., Radebaugh, L.H. \& Roberts, C.L., 1990, 'International perceptions of cost constraints on voluntary information disclosures: A comparative study of UK and
US multinationals', Journal of International Business Studies 21(4), 597-622. https://doi.org/10.1057/palgrave.jibs.8490343

Hassan, O. \& Marston, C., 2010, Disclosure measurement in the empirical accounting literature: A review article, Working paper at the Brussels University, viewed 29 July 2016, from http://ssrn.com/abstract $=1640598$

Healy, P.M., Hutton, A.P. \& Palepu, K.G., 1999, 'Stock performance and intermediation changes surrounding sustained increases in disclosure', Contemporary Accounting Research 16(3), 485-520. https://doi.org/10.1111/j.1911-3846.1999.tb00592.x

Healy, P.M. \& Palepu, K.G., 2001, 'Information asymmetry, corporate disclosure, and the capital markets: A review of the empirical disclosure literature', Journal of Accounting and Economics 31(1-3), 405-440. https://doi.org/10.1016/S01654101(01)00018-0

Heflin, F.L., Shaw, K.W. \& Wild, J.J., 2005, 'Disclosure policy and market liquidity: Impact of depth quotes and order sizes', Contemporary Accounting Research 22(4), 829865. https://doi.org/10.1506/EETM-FALM-4KDD-9DT9

Kyle, A., 1985, 'Continuous auctions and insider trade', Econometrica 53(6), 1315-1335. https://doi.org/10.2307/1913210

Lang, M.H. \& Lundholm, R.J., 1993, 'Cross-sectional determinants of analyst ratings of corporate disclosures', Journal of Accounting Research 31(2), 246-271. https:// corporate disclosures', Journ
doi.org/10.2307/2491273

Lang, M.H. \& Lundholm, R.J., 1996, 'Corporate disclosure policy and analyst behaviour', The Accounting Review 71(4), 467-492.

Lang, M.H. \& Lundholm, R.J., 2000, 'Voluntary disclosure and equity offerings: Reducing information asymmetry of hyping the stock?', Contemporary Accounting Research 17(4), 623-662. https://doi.org/10.1506/9N45-FOJX-AXVW-LBWJ

Leuz, C. \& Verrecchia, R.E., 2000, 'The economic consequences of increased disclosure', Journal of Accounting Research 38, 91-124.

Lev, B., 1988, 'Toward a theory of equitable and efficient accounting policy', The Accounting Review 63(1), 1-22.

Loxton, L., 2003, 'Beleggersverhoudinge op die Internet: 'n Ondersoek in Suid-Afrika', Meditari 11(1), 80-94. https://doi.org/10.1108/10222529200300006

Marston, C., 1996, 'The organisation of the investor relations function by large UK quoted companies', Omega 24(4), 477-488. https://doi.org/10.1016/03050483(96)00015-1 
Merton, R.C., 1987, 'A simple model of capital market equilibrium with incomplete information', The Journal of Finance 42(3), 483-510. https://doi. org/10.1111/j.1540-6261.1987.tb04565.x

Nel. G.F. \& Baard, R., 2006, 'Using corporate web sites in Africa to market to investors', South African Journal of Information Management 8(3), viewed 23 July 2012, from http://www.sajim.co.za

Nel, G.F. \& Brummer, L.M., 2016, 'The development of a measurement instrument to measure the quality of internet investor relations', South African Journal of Business Management 47(4), 15-25.

Nel, G.F., Smit, E.vd.M. \& Brummer, L.M., 2017, 'Determinants of the quality of internet investor relations - A study of companies listed on the JSE', South African Journal of Business Management 48(1), 55-65.
Orens, R., Aerts, W. \& Cormier, D., 2010, 'Web-based non-financial disclosure and cost of finance', Journal of Business Finance and Accounting 37(9), 1057-1093. https:// doi.org/10.1111/j.1468-5957.2010.02212.x

Trabelsi, S., Labelle, R. \& Dumontier, P., 2008, 'Incremental voluntary disclosure on corporate websites: Determinants and consequences', Journal of Contemporary Accounting \& Economics 4(2), 120-155. https://doi.org/10.1016/S18155669(10)70032-1

Venter, J.M.P., 2002, 'A survey of current online reporting practices in South Africa', Meditari 10(1), 209-225. https://doi.org/10.1108/10222529200200011

Welker, M., 1995, 'Disclosure policy, information asymmetry, and liquidity in equity markets', Contemporary Accounting Research 11(2), 801-827. https://doi. org/10.1111/j.1911-3846.1995.tb00467.x 